\title{
Comparative histomorphology of endocrine pancreas in deccani sheep and bidri goat
}

\begin{abstract}
The present study was conducted in six adult Deccani sheep and Bidri goats to know the histological structure of endocrine pancreas. Islets were distributed irregularly within the exocrine portion of the gland. The reticular fibers formed a boundary between the endocrine and exocrine portion. The islets were oval, round or irregular in shape and were classified into small, medium and large, based on their size on its long axis. Three types of cells $\alpha, \beta$ and $\delta$ were identified within the islets by special stains like Masson's trichrome, Modified aldehyde fuchsin stain method and Maldonado's method.
\end{abstract}

Keywords: histology, endocrine pancreas, islets, sheep, maldonado's method, deccani, histomorphological

\author{
Volume 3 Issue I - 2017 \\ Mahesh,' Gadre KM, ${ }^{2}$ Ashok P,' Girish HM, ${ }^{2}$ \\ Sharanagouda, ${ }^{3}$ Annapurana Awati $^{4}$ \\ 'Veterinary officer, Veterinary Dispensary Kannur, India \\ ${ }^{2}$ Department of Veterinary Anatomy and Histology, Veterinary \\ College, India \\ ${ }^{3}$ Veterinary officer, Veterinary Dispensary Madyal, India \\ ${ }^{4}$ Veterinary officer,Veterinary Dispensary Mashalla, India
}

Correspondence: Mahesh, Veterinary Officer, Veterinary Dispensary, kannur, Kalaburgi, India, 585316, Tel 08050968799 , Email chincholikar.vet@gmail.com

Received: April 02, 2016 | Published: January 25, 2017

\section{Introduction}

Small ruminant's pancreas is a major accessory organ and has an important role in digestion. Endocrine part of pancreas is Islets of Langerhans which are highly vascularized, consisting of several endocrine cell types that function together to maintain glucose homeostasis. There has been limited scientific work done on the histomorphological study of pancreas in Deccani sheep Bidri goat. The present research was conducted to analyze and compare the general histomorphology of endocrine pancreas in both the species. It may also useful in future for transplantation of pancreatic cells, stem cell regeneration, tissue engineering and in vitro studies. Therefore, for better understanding of pancreatic histomorphology in humans. Hence the present research work was undertaken.

\section{Material and methods}

The present study was carried out in the Department of Veterinary anatomy and Histology, Veterinary College, Bidar, Karnataka. The materials for the study were collected from six adult Deccani sheep and Bidri goat, immediately after slaughter from local slaughter houses. The collected tissue pieces were washed in normal saline later, they were fixed in different fixatives like normal buffered formalin, bouin's solution and zenker's solution. The tissue pieces were processed and embedded in paraffin by routine method. Sections were cut at 4-6 $\mu \mathrm{m}$ thickness and were utilized for histomorphological studies.

\section{Results and discussion}

There was no particular pattern of distribution of islets of Langerhans in different parts of the gland in both Deccani sheep and Bidri goat. Similar findings were reported by Meshram ${ }^{1}$ in goat. However, Baltazar et al., ${ }^{2}$ reported that islets were more concentrated in the right lobe than in the left lobe and body of pancreas in Philippine carabao.

Islets were round, oval or irregular in shape and were present irregularly within the exocrine portion and also in the interlobular connective tissue (Figure $1 \&$ Figure 2). These results were in agreement with findings of Malik et al., ${ }^{3}$ in cattle and buffalo, Banks ${ }^{4}$ in domestic animals and Ladukar et al., ${ }^{5}$ in buffalo. Pancreatic islets were partially encapsulated by few reticular fibers in both species. These findings were in accordance with the observations of Gangul et al., ${ }^{6}$ in goat and Trautmann et al., ${ }^{7}$ in mammals. However, the number of reticular fibers was more in Deccani sheep than in Bidri goat. Some of the small islets contained only one, two or three cells in both species which was in agreement with Mukherjee et al., ${ }^{8}$ who reported unicellular islets in sheep (Figure 3 \& Figure 4).

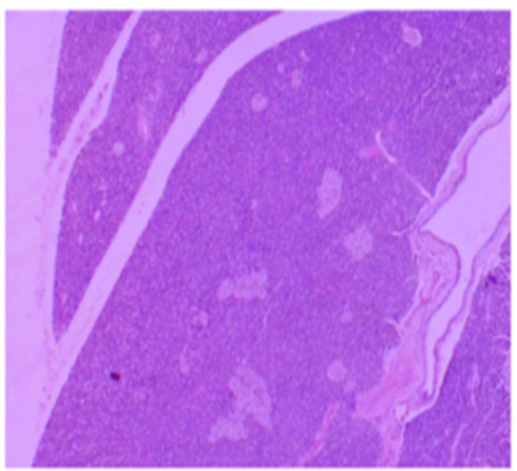

Figure I Photomicrograph of pancreas of adult Bidri goat showing islets with different shape and sizes (arrow) within the exocrine portion (A). H \& Ex4

In the present study small, medium and large islets were observed in both species and the length of islets was measured in its long axis. Statistically there was no significant difference in the length of islets in both Bidri goat and Deccani sheep. Small islets ranged from $16.05 \mu \mathrm{m}$ to $48.58 \mu \mathrm{m}$ in Bidri goat and $10.26 \mu \mathrm{m}$ to $45.61 \mu \mathrm{m}$ in Deccani sheep. Medium size islets ranged from $49.98 \mu \mathrm{m}$ to $87.11 \mu \mathrm{m}$ in Bidri goat and $49.21 \mu \mathrm{m}$ to $88.88 \mu \mathrm{m}$ in Deccani sheep. Large islets ranged from $91.75 \mu \mathrm{m}$ to $164.44 \mu \mathrm{m}$ in Bidri goat and $90.70 \mu \mathrm{m}$ to $162.83 \mu \mathrm{m}$ in Deccani sheep. These findings were contrary to the findings of Vijayaraghavan et al. ${ }^{9}$ who reported that small islets ranged from $17.06 \mu \mathrm{m}$ to $70.30 \mu \mathrm{m}$ and large islets from $98.42 \mu \mathrm{m}$ to $168.72 \mu \mathrm{m}$ on longitudinal axis in buffalo. 


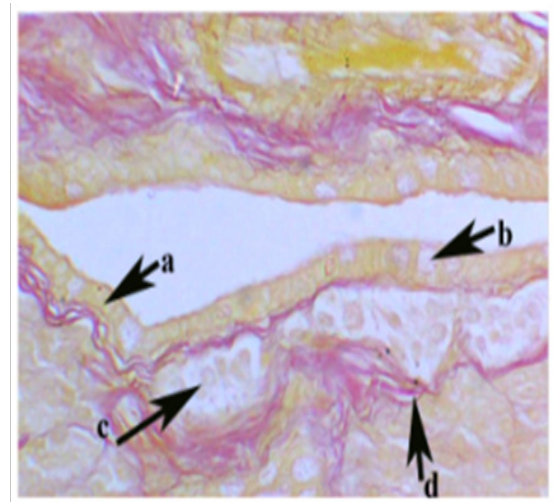

Figure 2 Photomicrograph of pancreas of adult Deccani sheep showing interlobular duct (A), goblet cell (B), islet (C) within the interlobular connective tissue (D) Gomori's Aldehyde Fuchsin stain $\times 40$.

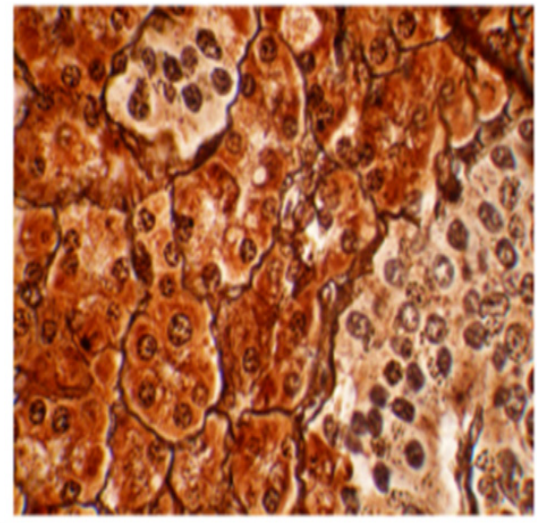

Figure 3 Photomicrograph of pancreas of adult Deccani sheep showing reticular fibres (arrow) around the islet. Gomori's reticulum stain $\times 100$.

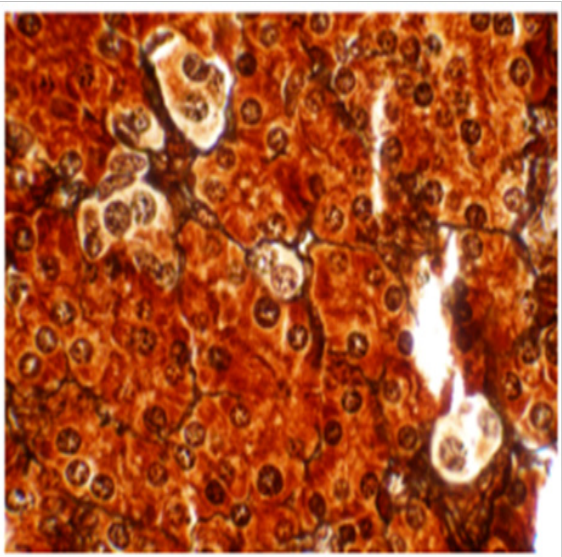

Figure 4 Photomicrograph of pancreas of adult Deccani sheep showing only two, three cells in a pancreatic islets (arrow).

Three types of cells viz; alpha, beta and delta cells were observed within the islets of Langerhans in both Deccani sheep and Bidri goat (Figure $5 \&$ Figure 6). Similar observations were reported by Dhoolappa ${ }^{10}$ in Indian donkey and Eurell et al., ${ }^{11}$ in domestic animals who also observed alpha, beta and delta cells. However, Mukherjee et al., ${ }^{8}$ Bacha et al. ${ }^{12}$ in sheep, Gangul et al. ${ }^{6}$ in goat; Ladukar et al. ${ }^{13}$ and Vijayaraghavan et al. ${ }^{9}$ in buffalo reported only two types of cells.

Alpha cells were placed peripherally, while beta cells towards the centre of islets. Similar observations were reported by Monroe et al., ${ }^{14}$ in dog and man and Ladukar et al. ${ }^{13}$ in buffalo. However, Frossmann ${ }^{15}$ in equine and Dhoolappa ${ }^{10}$ in Indian donkey reported alpha cells towards centre and beta cells towards the periphery. This variation may be attributing to species variation. Beta cells were purple - violet, alpha cells were yellow and delta cells appeared green with modified aldehyde fuchsin stain (Figure 6).

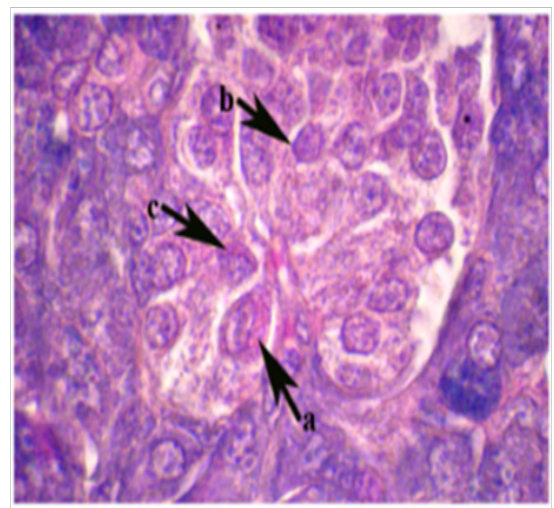

Figure 5 Photomicrograph of pancreas in Bidri goat showing alpha cells (A), beta cells $(B)$ and delta cells $(C)$ Gomori's method for pancreatic islets $\times 100$.

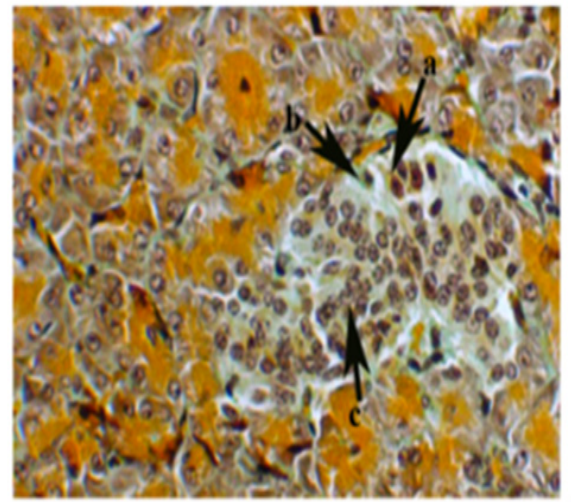

Figure 6 photomicrograph of pancreas in Deccani sheep showing alpha cells (A), beta cells (B) and Delta cell (C) modified Aldehyde fuchsin stain $\times 40$.

\section{Acknowledgements}

Authors are grateful to the Department of Veterinary anatomy and histology, veterinary college, Nandi nagar, Bidar, for providing facilities to carrying out this research. The authors are also thankful to the Vice Chancellor of karnataka veterinary, animal and fisheries sciences university, Bidar.

\section{Conflict of interest}

Author declares that there is no conflict of interest.

\section{References}

1. Meshram BN. Age related histomorphological and histochemical changes in pancreas of goat (Capra hircus). MVSc thesis, Punjab Rao Krishi Vidyapeeth, Akola (Maharastra), India; 2000.

2. Baltazar ET, Maala CP, Landicho EF. Histology of the pancreatic islets of the philippine carabao (Bubalus bubalis). The Philippine Agricultural Scientist. 2001;84(3):278-228.

3. Malik MR, Prem Prakash. Comparative histology of pancreas of buffalo and ox, A note. Ind J Ani Sci. 1972;42(9):681-682. 
4. Banks WJ. Applied veterinary histology. 3rd ed. USA: Mosby-Year Book Inc; 1993. p. 371-373.

5. Ladukar ON, Pandit RV. Nerve supply to buffalo pancreas, peri-insular plexus. Indian Vet J. 1995;72(10):1061-1064.

6. Gangul A, Prasad G. Histology of goat pancreas. Proceedings of the XI annual convention of Indian association of veterinary anatomist and national symposium on recent advances in the anatomy of domestic animals.56. 1996.

7. Trautmann A, Fiebiger J. Fundamentals of the domestic animals. India: First Indian Reprint, Green world Publishers; 2002. p. 216-219.

8. Mukherjee G, Singh LP, Barnwal AK, et al. Endocrine pancreas of sheep. Ind J Ani Sci. 1988;58(1):91-93.

9. Vijayraghavan C, Mariappa D. Histological observations on the pancreas of Indian Buffalo (Bubalus bubalis). Cheiron. 1972;5(2):115-118.
10. Dhoolappa M. Macro and micro anatomy of liver and pancreas in Indian donkey. Dharwad: MVSc thesis, University of Agricultural sciences; 2002 .

11. Eurell JA, Frappier BL. Dellman's Textbook of Veterinary Histology. 6th ed. Philadelphia: Lea and Feibiger; 2006. p. 255-257.

12. Bacha WJ, Bacha LM. Atlas of Veterinary Histology. 2nd ed. India: Lippin Cott Williams and Wilkins; 2000. p. 155-156.

13. Ladukar ON, Pandit RV. Identification of cells of islets of Langerhan's of buffalo Pancreas by Bielschowsky's Silver Impregnation Method. Cherion. 1992;21(2):56-59.

14. Monroe CW, Spector B. Tannic acid iron haematoxylene, Alcian blue and basic fuchsin for staining islets, reticular fibres of the pancreas. Stain Technol. 1963;38:187-192.

15. Forssmann A. The ultrastructure of the cell types in the endocrine pancreas of the horse. Cell Tissue Res. 1976;167(2):179-195. 